\title{
Group-affiliated Firms and Corporate Social Responsibility Activities
}

\author{
Woo Jae Lee ${ }^{1}$
}

Received : September 13, 2018 Revised: September 22, 2018 Accepted: September 30, 2018

\begin{abstract}
Corporate social responsibility (CSR) is one of the strategies for managing firms' business activities but may have heterogeneity depending on ownership structures. This study investigates the association between group-affiliation and CSR activities. Drawing on a theory from the prior research, this study predicts that group-affiliated firms are less likely to invest on CSR activities. For instance, prior research finds that controlling shareholders expropriate the values of minority shareholders. As one of the motivations of investing on CSR activities is the harmonization among the stakeholders, it leads to the prediction that firms controlled by large shareholders are less likely to engage in CSR activities. Second, group-affiliated firms under poor financial performance benefit from other group members through sharing their financial resources. Thus, there is less incentive for managers of group-affiliated firms to increase their financial performance by conducting CSR. By leveraging firms listed in Korean stock market and CSR score from Korea Economic Justice Institute, the result shows that the groupaffiliation is negatively related to CSR activities. The result is consistent in case of applying propensity score-matched sample. Based on the findings of this study, this paper contributes to the related literature by showing the significant association between group-affiliation and CSR decisions.
\end{abstract}

Keywords: Group Affiliation, Business Group, Corporate Social Responsibility, Propensity Score Matching, Korea.

JEL Classification Code: M14, M40, M41.

\section{Introduction}

Corporate social responsibility (CSR) is one of the strategies for managing firms' business activities but may have heterogeneity depending on ownership structures. The focus of this study is on the impact of belonging to a group on CSR activities. South Korea offers an interesting setting for investigating the link between group-affiliated firms and CSR activities. Considerable numbers of firms are the members of business group. For instance, there are 60 business groups and 2,083 affiliated firms in Korea as of May 2018 (Fair Trade Commission, 2018). Usually, controlling owners are now the descendants of the group founders who operate firms with both direct and indirect equity stakes.

1 First Author and Corresponding Author. Visiting Professor, College of Economics and Management, Chungnam National University, South Korea [Postal Address: 99 Daehak-ro, Yuseong-gu, Daejeon, 34134, South Korea]

Tel: +82-42-821-7108, E-mail: woojae.lie@gmail.com
Drawing on a theory from the prior research, this study predicts that group-affiliated firms are less likely to invest on CSR activities. Previous studies suggest the two motives of performing CSR. Those are 1) ethical responsibilities and 2) opportunistic incentives. First, from the view point of ethical responsibilities, it is well known that group-affiliated controlling owners are less likely to consider the wealth of minority shareholders. Prior research generally argues that controlling shareholders expropriate the values of minority shareholders (Chang, 2003; La Porta, Lopez-de-Silanes, \& Shleifer, 1999). As one of the motivations of investing on CSR activities is the harmonization among the stakeholders, it is expected that firms controlled by large shareholders are less likely to engage in CSR activities. Moreover, standalone firms have more incentives to conduct CSR activities to enhance their reputation. However, a firm belongs to a large business group can rely on the reputation of the business group. Second, a group-affiliated firm benefits from other group members through sharing their financial resources. For instance, Bae, Kang, and Kim (2002) and Chang (2003) show that group-affiliated firms could use 
resources of other group members when they suffer from low financial performance. Thus, by applying the opportunistic incentives theory, there is also less incentive for managers of affiliated firms to increase their financial performance by conducting CSR.

To investigate the effect of group-affiliation on CSR, this paper uses CSR scores provided by Korea Economic Justice Institute. The group-affiliation data is download from the website of Fair Trade Commission. Using Korean listed firms from year 2013 to 2016, this study finds that groupaffiliated firms are less engaged in CSR activities. The result is consistent in case of applying propensity score matched sample.

The paper contributes to the literature in the following ways. First, as previous studies focus on the firm-level determinants of CSR, this paper further extends the literature by introducing the group-affiliation as an important factor that affects CSR activities. Second, this study summarizes the motives of conducting CSR into two different incentives. Future research can examine the outcomes of investing CSR by drawing on these two motives into their research questions. Finally, Korean firms have a unique ownership structure known as a business group. Future studies can investigate other corporate decisions and the economic consequences of groupaffiliated firms.

The remaining of this paper proceeds as follows. Section II presents prior research and develops hypothesis. Section III describes research design. Section IV reports empirical findings and Section $V$ concludes the paper.

\section{Prior Literature and Hypothesis Development}

\subsection{Motivations and Consequences of Engaging in CSR Activities}

Prior research documents that the CSR activities are motivated by manager's two different incentives. On the one hand, managers conduct CSR activities for ethical and trustworthy incentives. Early studies suggest that every firms should conduct CSR as an ethical obligation (Carroll, 1979; Jones, 1995). For instance, Jones (1995) posits that firms with trusting and cooperative relationships with stakeholders prevent or reduce opportunism and will have a competitive advantage. Recent empirical evidences also support this view. For instance, Kim, Park, and Wier (2012) find a negative relation between CSR and earnings management. They interpret the result that firms who are deeply engaged in CSR are more prudent in financial reporting to serve stakeholders.

On the other hand, theories suggest that CSR is a strategy for opportunistic behavior rather than for the trust of stakeholders (Jensen \& Meckling, 1976). Consistent with this view, Prior, Surroca, and Tribó (2008) find that firms perform CRS activities in order to disguise earnings management. As a consequence, they find a negative financial performance for the firms with the combination of earnings management and CSR activities. Dhaliwal, Li, Tsang, and Yang (2011) find that the firms with a high cost of equity capital tend to initiate disclosure of CSR in order to reduce their equity raising costs. They further document that this initiation attracts institutional investors and analysts as a consequence. Similarly, El Ghoul, Guedhami, Kwok, and Mishra (2011) find that firms with better CSR scores reduce cost of equity capital. In particular, they examine and document that investment in improving responsible employee relations, environmental policies, and product strategies are related with lower cost of capital. In summary, since there is more than a single motive of CSR activities, it is necessary to consider these different incentives when testing the determinants of CSR.

\subsection{Features of Group-affiliated Firms}

A group of firms those who are controlled by one large shareholder is known as a Business group. All the affiliated firms of this business group are group-affiliated firms. The ownership structure of this group-affiliated firms differ from that of the other non-affiliated firms. Thus, the features of affiliated firms are apart from the predictions of traditional agency theory. Controlling shareholders' voting right usually exceed cash flow right via pyramid structures which enables them to expropriate minority shareholders' wealth. This kind of ownership structure is widely spread on East Asian countries (Claessens, Djankov, \& Lang, 2000).

Because of this unique feature, the performance of the business group has been controversial issues. On the one hand, previous studies find a negative association between group-affiliated firms and performance. Chacar and Vissa (2005) investigate and find that firms that are affiliated with a business group have a greater persistence of poor performance than that of unaffiliated firms in emerging economies. On the other hand, Anderson and Reeb (2003) insist that family group members perform better than nonfamily members suggesting that family ownership is an effective organizational structure. Some studies find that this positive association is conditional to several factors. For instance, by using Indian firms, Khanna and Palepu (2000) argue that group-affiliated firms of the most diversified business groups outperform unaffiliated firms. Using Taiwan 
firms, Chu (2004) find that large business group member firms show higher stock market performance but small business group members suffer from their poor performance. Using Chinese firms, Ma, Yao, and Xi (2006) show that the interaction of business group affiliation and state ownership has a positive effect on firm performance.

Being more focused on the studies of Korean firms, Chang and Hong (2000) show that by sharing intangible and financial resources, Korean group-affiliated firms obtain their competitive advantage accompanied by fast economic growth. Studies also find that group-affiliated firms benefit from the membership through sharing resources of other member firms. This is known as a "tunneling" which has been examined from numerous previous studies. Several papers find the evidence of a tunneling in Korean groupaffiliated firms. For instance, Bae, Kang, and Kim (2002) document that stock price falls when a group-affiliated firm makes an acquisition. This is an evidence of tunneling because controlling shareholder of that firm on average gets benefits as the acquisition enhances the value of other firms in the group while minority shareholders making an acquisition lose. Similarly, Chang (2003) investigates and finds that controlling shareholders use insider information to take equity stakes and transfer profits to affiliates through intragroup trade.

\subsection{Hypothesis Development}

The two incentives that motivate firms to engage in CSR activities are ethical responsibilities and opportunistic incentives. This is based on the theory offered by Carroll (1979). The study suggests that CSR firms should obey the law, be ethical, and be a good entity supported by good financial condition. Thus, firms acting as a socially good entity not only follow the law but also have to conduct ethical behavior and have to report good financial performance. From these two motives this study predicts that groupaffiliated firms would less preform CSR activities.

First, from the view point of ethical responsibilities, it is well known that group-affiliated controlling owners are less likely to consider the wealth of minority shareholders. Theory suggests that large business groups are less likely to suffer from agency costs. Agency costs refer to the conflict between owner and manager causing from outside managers' opportunistic personal behavior by satisfying owners' wealth (Jensen \& Meckling, 1976). However, firms both owned and managed by controlling shareholders reveal different aspects from this traditional agency problem. Prior research generally argues that controlling shareholders expropriate the values of minority shareholders (Chang, 2003; La Porta, Lopez-de-Silanes, \& Shleifer, 1999). There are evidences that firms are less affected by stakeholders' monitoring mechanisms when they are managed by controlling shareholders rather than the managers from outside. Bae, Kang, and Kim (2002) show that group-affiliated firms make an acquisition that leads to losses in minority shareholders but enhances the value of other members in the group. This evidence, known as a tunneling, prevails in group-affiliated business group. As the first motivation of CSR activities aforementioned considers the harmonization among the stakeholders, it is expected that firms controlled by large shareholders are less likely to engage in CSR activities.

Second, by drawing on an opportunistic incentive, the negative association between group-affiliation and CSR is also expected. Firms must have adequate funds to run a business. Firms belonging to a group benefit from other group members through sharing financial resources. In this respect, group-affiliated firms have a competitive advantage than non-affiliated firms. In particular, prior studies find that group members show various forms of internal transactions among inside memberships. For instance, Chang and Hong (2000) find that group-affiliated firms share intangible and financial resources with other member firms. Bae, Kang, and Kim (2002) and Chang (2003) show that group-affiliated firms could use resources of other group members when they suffer from low financial performance. In summary, there is less incentive for managers of affiliated firms to increase their financial performance by conducting opportunistic behavior. Discussion from these studies leads to the following hypothesis.

\section{Hypothesis: Group-affiliated firms are less engaged in} CSR activities than that of unaffiliated firms.

\section{Research Design}

\subsection{The Sample}

The sample consists of firm-year from 2013 to 2016. The sample period starts in year 2013 because CSR score has been newly updated since this year. This study uses the observations that satisfy: firms do not operate in financial industries, listed firms with available financial data for calculating the variables used in this study, firms whose group-affiliations are identified.

This study collects the financial data from Total Solution (TS) 2000 database provided by Korea Listed Companies Association. The final sample consists of 749 firm-year observations. Table 1 presents the yearly distributions. The number of firms by years are generally stable. In particular, there are 187 firms in 2013 and 185 firms in 2016. 
Table 1: Yearly distribution

\begin{tabular}{|c|c|c|c|c|c|}
\hline Year & $\mathbf{2 0 1 3}$ & $\mathbf{2 0 1 4}$ & $\mathbf{2 0 1 5}$ & $\mathbf{2 0 1 6}$ & Total \\
\hline $\mathrm{N}$ & 187 & 191 & 186 & 185 & 749 \\
\hline
\end{tabular}

\subsection{Main Variables}

\subsubsection{Group Affiliation}

This study manually downloads group affiliation identifier at the website of Fair Trade Commission (http://groupopni.ftc.go.kr). The business group on this FTC homepage generally exclude relatively small business group, and therein this study adds these small groups from the TS 2000 database.

\subsubsection{CSR Score}

In South Korea, the Korea Economic Justice Institute (KEJI) provides the "Best corporate citizen index" which is largely used as a CSR index from the prior research. KEJI started to give "Economic Justice Corporation" award to a firm who actively participate on CSR activities since 1991. They also report detailed CSR index since year 2004 and the evaluation method has been continuously improved. Our sample period starts from year 2013 and the index provides CSR scores of the top 200 listed firms. KEJI's CSR index is calculated by the following three procedures. 1) Calculate the actual value of a given indicator. 2) Converts actual values to 100 points scale based on the rating formula. 3) Calculate a final score weighted by indicator. The CSR score used in the study is a final score after applying above three procedures. In particular, there are six categories used as indicators. Those are soundness (25 points), fairness (20 points), social contribution (15 points), consumer protection (15 points), environmental management (10 points), and employee satisfaction (15 points).

\subsection{Research Model}

This study uses the following regression model to test the hypothesis:

$$
\begin{aligned}
\text { CSR }_{i, t}= & \alpha_{0}+\alpha_{1} \text { Group }_{i, t}+\alpha_{2} \text { Size }_{i, t}+\alpha_{3} \text { Lev }_{i, t}+\alpha_{4} \text { ROA }_{i, t} \\
& +\alpha_{5} \text { Loss }_{i, t}+\alpha_{6} \text { CF }_{i, t}+\alpha_{7} G R W_{i, t}+\alpha_{8} \text { INVREC }_{i, t}+\text { Year FE } \\
& + \text { Industry FE }+\varepsilon_{i, t}
\end{aligned}
$$

Where, CSR is a CSR score from the KEJI database; Group is an indicator variable equals to one if a firm is affiliated and zero otherwise; Size is natural logarithm of total assets; Lev is calculated as total liabilities divided by total assets; ROA is net income divided by total assets; Loss equals to one if a firm reports loss and zero otherwise; $C F$ is operating cash flows divided by total assets; GRW is asset growth rate; INVREC is a sum of inventories and receivables divided by total assets; Year FE and Industry FE are the year and industry fixed dummies.

This study expects the coefficient of Group (a1) to be negatively significant to supports the hypothesis. To avoid the omitted variable problem, several control variables are included. First, firm size (Size) is included. Larger firms have economies of scales as they can save costs by spreading out the cost of CSR into many different divisions than small firms (McWilliams \& Siegel, 2001). Financial leverage ratio (Lev) is included to control the impact of financial conditions on CSR decisions. As prior research finds a positive relation between CSR and financial performance (McGuire, Sundgren, \& Schneeweis, 1988; Waddock \& Graves, 1997), $R O A$, Loss and CF are included. To mitigate the effect of growth rate and operating complexity on CSR, GRW and INVREC are included. Finally, Year FE and Industry FE are included to control the year and industry specific events.

\section{Empirical Findings}

\subsection{Descriptive Statistics and Correlation Matrix}

Table 2 reports descriptive statistics and Pearson correlation. Panel A of Table 2 presents descriptive statistics of main variables. All the continuous variables are winsorized at the top and bottom 1 percent. The mean value of CSR which represents the KEJI's CSR score is 63.643 . The highest score that firms can be rewarded is 100 while the 99 percentile score of the sample is 69.230 . This shows that Korean listed firms generally do not aggressively invest on CSR activities. The mean value of Group is 0.522 , and therein the two groups (affiliated and unaffiliated) are almost equally distributed. The mean values of Size, Lev, and ROA are $19.810,0.364$, and 0.052 , respectively which are generally consistent with prior research. The other controls also reveal comparable numbers to previous studies.

Panel B of Table 2 shows Pearson correlations. The correlation between Group and CSR is not significant. However, interpretation before controlling other variables needs to be cautious. Size, ROA have positive correlations with CSR supporting slack resources hypothesis (Waddock \& Graves, 1997). GRW is also positively associated with CSR. Size is positively related with Group while INVREC is negatively related. This implies that large firms with less complex operating environment are affiliated with business group. 
Table 2: Descriptive statistics and Correlation matrix

\begin{tabular}{|c|c|c|c|c|c|c|c|}
\hline \multicolumn{8}{|c|}{ Panel A: Descriptive statistics ( $\mathrm{N}=749)$} \\
\hline Variable & Mean & Std. & $1 \%$ & $25 \%$ & Median & $75 \%$ & $99 \%$ \\
\hline CSR & 63.643 & 2.125 & 59.300 & 62.290 & 63.420 & 64.980 & 69.230 \\
\hline Group & 0.522 & 0.500 & 0.000 & 0.000 & 1.000 & 1.000 & 1.000 \\
\hline Size & 19.810 & 1.293 & 17.563 & 18.982 & 19.581 & 20.365 & 24.014 \\
\hline LeV & 0.364 & 0.178 & 0.046 & 0.229 & 0.341 & 0.505 & 0.820 \\
\hline$R O A$ & 0.052 & 0.043 & -0.033 & 0.021 & 0.044 & 0.074 & 0.217 \\
\hline Loss & 0.036 & 0.187 & 0.000 & 0.000 & 0.000 & 0.000 & 1.000 \\
\hline$C F$ & 0.069 & 0.059 & -0.073 & 0.032 & 0.064 & 0.103 & 0.258 \\
\hline GRW & 0.043 & 0.082 & -0.226 & -0.001 & 0.036 & 0.081 & 0.318 \\
\hline INVREC & 0.291 & 0.138 & 0.002 & 0.193 & 0.292 & 0.384 & 0.620 \\
\hline
\end{tabular}

\begin{tabular}{|c|c|c|c|c|c|c|c|c|c|}
\hline \multicolumn{10}{|c|}{ Panel B. Pearson Correlation } \\
\hline & 1. & 2. & 3. & 4. & 5. & 6. & 7. & 8. & 9. \\
\hline 1. CSR & 1.000 & & & & & & & & \\
\hline 2. Group & 0.009 & 1.000 & & & & & & & \\
\hline 3. Size & 0.171 & 0.367 & 1.000 & & & & & & \\
\hline 4. LeV & -0.082 & 0.084 & 0.154 & 1.000 & & & & & \\
\hline 5. ROA & 0.124 & -0.038 & 0.019 & -0.249 & 1.000 & & & & \\
\hline 6. LOSS & -0.001 & 0.013 & -0.017 & 0.133 & -0.320 & 1.000 & & & \\
\hline 7. $C F$ & 0.039 & 0.029 & 0.138 & -0.147 & 0.512 & -0.118 & 1.000 & & \\
\hline 8. GRW & 0.152 & 0.010 & -0.026 & 0.116 & 0.383 & -0.130 & -0.054 & 1.000 & \\
\hline 9. INVREC & -0.044 & -0.097 & -0.296 & 0.269 & -0.019 & 0.019 & -0.099 & 0.090 & 1.000 \\
\hline
\end{tabular}

Bold typefaces indicate significance of $1 \%$ or higher level.

\subsection{Empirical Results}

Table 3 presents the main results of the hypothesis. The dependent variable is CSR and the variable of interest is Group. All the significance-levels are controlled after heteroscedasticity-consistent. The coefficient of Group is negative and significant at the 5 percent level (coefficient =0.310 , t-value=-2.25). Thus, group-affiliated firms are less likely to engage in CSR activities. This result supports the hypothesis. Although untabulated, the results of using pooled OLS estimator or firm-level clustered estimator show the similar evidences.

Further, the coefficients of control variables are also consistent with prior research. For instance, Size, ROA and GRW are positively associated with CSR while Lev is negatively associated. This evidences show that a firm with sufficient resources invest more on CSR.

\subsection{Additional Test}

Propensity score matching (PSM) has become a popular method for mitigating endogeneity issues in accounting and finance literature (Armstrong, Jagolinzer, \& Larcker, 2010; Lawrence, Minutti-Meza, \& Zhang, 2011; Minutti-Meza 2013). Even though recent studies document that PSM is not the right technique for addressing endogeneity, it has been a trend in these research area to include the results using sample produced by PSM (i.e., Shipman, Swanquist, \& Whited, 2016). Thus, this study uses PSM approach to
Table 3: CSR activities of group-affiliated firms

\begin{tabular}{|c|c|c|}
\hline \multirow{2}{*}{ Independent Variable } & \multicolumn{2}{|c|}{ Dependent variable = CSR } \\
\cline { 2 - 3 } & Coefficient & (t-stat) \\
\hline Intercept & $58.682^{* * *}$ & $(44.71)$ \\
\hline Group & $-0.310^{* *}$ & $(-2.25)$ \\
\hline Size & $0.314^{* * *}$ & $(4.87)$ \\
\hline Lev & $-0.823^{*}$ & $(-1.89)$ \\
\hline ROA & $3.595^{*}$ & $(1.70)$ \\
\hline Loss & 0.405 & $(1.26)$ \\
\hline CF & 0.281 & $(0.20)$ \\
\hline GRW & $2.457^{* * *}$ & $(2.98)$ \\
\hline INVREC & 0.169 & $(0.30)$ \\
\hline Year \& Industry & \multicolumn{2}{|c|}{ Included } \\
\hline Adj. R & \multicolumn{3}{|c|}{74080} \\
\hline N & \multicolumn{2}{|c|}{} \\
\hline
\end{tabular}

Heteroscedasticity-consistent estimator is used in the regression model. *, ${ }^{* *}$, and ${ }^{* * *}$ indicate significance level at the $10 \%, 5 \%$, and $1 \%$, respectively.

demonstrate the robustness of the previous result. PSM has two step procedures. In the first stage, treatment group (group-affiliated firms) are matched with control group (unaffiliated firms) by generated propensity scores. In the second stage, the hypothesis is tested by using the matched sample.

Following Shipman, Swanquist, and Whited (2016), this study uses the same control variables used in the main hypothesis tests as independent variables of the first stage 
Probit regression. This is necessary because including other variables may cause self-selection bias. The analysis in this study imposes a 3 percent caliper distance restriction for a successful match (Lawrence, Minutti-Meza, \& Zhang, 2011). After matching one treatment firm to one control firm (oneto-one match), the final sample consists of 99 affiliated and 99 unaffiliated firms.

Table 4: Propensity score matching test

\begin{tabular}{|c|c|c|}
\hline \multirow{2}{*}{ Panel A. First stage Probit regression } \\
\hline \multirow{2}{*}{ Independent Variable } & \multicolumn{2}{|c|}{ Dependent variable = Group } \\
\cline { 2 - 3 } & Coefficient & (Chi-Square) \\
\hline Intercept & -8.616 & $(0.00)$ \\
\hline Size & $0.899^{* * *}$ & $(74.71)$ \\
\hline Lev & -0.445 & $(0.48)$ \\
\hline ROA & -3.224 & $(0.99)$ \\
\hline LosS & 0.437 & $(0.82)$ \\
\hline CF & 2.460 & $(1.49)$ \\
\hline GRW & $2.428^{*}$ & $(3.27)$ \\
\hline INVREC & $2.852^{* * *}$ & $(9.56)$ \\
\hline Year \& Industry & \multicolumn{3}{|c|}{ Included } \\
\hline Pseudo R & \multicolumn{3}{|c|}{749} \\
\hline $\mathrm{N}$ & \multicolumn{3}{|c|}{} \\
\hline
\end{tabular}

\begin{tabular}{|c|c|c|}
\hline \multirow{2}{*}{ Panel B. Second stage regression } \\
\hline \multirow{2}{*}{ Independent Variable } & \multicolumn{2}{|c|}{ Dependent variable = CSR } \\
\cline { 2 - 3 } & Coefficient & (t-stat) \\
\hline Intercept & $53.436^{* * *}$ & $(13.62)$ \\
\hline Group & $-0.635^{* * *}$ & $(-3.01)$ \\
\hline Size & $0.544^{* * *}$ & $(2.74)$ \\
\hline Lev & -0.262 & $(-0.29)$ \\
\hline ROA & $-6.967^{*}$ & $(-1.74)$ \\
\hline LoSS & -0.322 & $(-0.75)$ \\
\hline CF & $6.961^{* * *}$ & $(2.96)$ \\
\hline GRW & $6.476^{* * *}$ & $(3.75)$ \\
\hline INVREC & -0.240 & $(-0.18)$ \\
\hline Year \& Industry & \multicolumn{2}{|c|}{ Included } \\
\hline Adj. $R^{2}$ & \multicolumn{3}{|c|}{0.3706} \\
\hline $\mathrm{N}$ & \multicolumn{3}{|c}{} \\
\hline
\end{tabular}

Heteroscedasticity-consistent estimator is used in the regression model. ${ }^{*},{ }^{* *}$, and ${ }^{* * *}$ indicate significance level at the $10 \%, 5 \%$, and $1 \%$, respectively. Panel B uses 99 affiliated and 99 unaffiliated observations.

The result of using this matched sample is shown in Table 4. Panel A presents first stage probit regression. The dependent variable is a Group. Similar to the previous findings, Size, GRW and INVREC are positively associated with Group. Panel B shows the result of testing the hypothesis using a matched sample. The coefficient of
Group is negative and significant at the 1 percent level (coefficient $=-0.635, \mathrm{t}$-value $=-3.01$ ). Thus, the result is robust after controlling the potential endogeneity problems (i.e., firm-specific characteristics) contained in groupaffiliated firms.

\section{Conclusion}

This study investigates the impact of group-affiliation on CSR activities. Drawing on a theory from the prior research, this study predicts that group-affiliated firms are less likely to invest on CSR activities. By leveraging a sample of Korean listed firms from year 2013 to 2016, the evidence shows that group-affiliated firm are less engaged in CSR activities. The results are consistent in case of applying propensity score matched sample.

The paper contributes to the literature in the following ways. First, this paper provides that group-affiliation is an important factor that affects CSR activities. While previous studies generally focus on the firm-level determinants, this paper sheds light on this area by suggesting interesting setting. Second, future research can examine the outcomes of investing CSR by drawing on the two motives which are summarized in this study. Finally, future studies can also investigate other corporate decisions and the economic consequences of group-affiliated firms using Korean business group.

\section{References}

Anderson, R. C., \& Reeb, D. M. (2003). Founding family ownership and firm performance: evidence from the S\&P 500. The Journal of Finance, 58(3), 1301-1328.

Armstrong, C. S., Jagolinzer, A. D., \& Larcker, D. F. (2010). Chief executive officer equity incentives and accounting irregularities. Journal of Accounting Research, 48(2), 225271.

Bae, K. H., Kang, J. K., \& Kim, J. M. (2002). Tunneling or value added? Evidence from mergers by Korean business groups. The Journal of Finance, 57(6), 2695-2740.

Carroll, A. (1979). A three-dimensional conceptual model of corporate performance. The Academy of Management Review, 4(4), 497-505.

Chacar, A., \& Vissa, B. (2005). Are emerging economies less efficient? Performance persistence and the impact of business group affiliation. Strategic Management Journal, 26(10), 933-946.

Chang, S. J. (2003). Ownership structure, expropriation, and performance of group-affiliated companies in Korea. Academy of Management Journal, 46(2), 238-253. 
Chang, S. J., \& Hong, J. (2000). Economic performance of group-affiliated companies in Korea: Intragroup resource sharing and internal business transactions. Academy of Management Journal, 43(3), 429-448.

Chu, W. (2004). Are group-affiliated firms really more profitable than nonaffiliated? Small Business Economics, 22(5), 391-405.

Claessens, S., Djankov, S., \& Lang, L. H. (2000). The separation of ownership and control in East Asian corporations. Journal of Financial Economics, 58(1-2), 81112.

Dhaliwal, D. S., Li, O. Z., Tsang, A., \& Yang, Y. G. (2011). Voluntary nonfinancial disclosure and the cost of equity capital: The initiation of corporate social responsibility reporting. The Accounting Review, 86(1), 59-100.

El Ghoul, S., Guedhami, O., Kwok, C. C., \& Mishra, D. R. (2011). Does corporate social responsibility affect the cost of capital? Journal of Banking \& Finance, 35(9), 23882406.

Fair Trade Commission. (2018). There are 60 business groups and 2,083 affiliated firms in Korea. Retrieved September 22, 2018 from http://groupopni.ftc.go.kr/ ogroup/index.jsp

Jensen, M., \& Meckling, W. (1976). Theory of the firm: Managerial behavior, agency cost and capital structure. Journal of Financial Economics, 3(4), 305-360.

Jones, T. M. (1995). Instrumental stakeholder theory: A synthesis of ethics and economics. Academy of Management Review, 20(2), 404-437.

Khanna, T., \& Palepu, K. (2000). Is group affiliation profitable in emerging markets? An analysis of diversified Indian business groups. The Journal of Finance, 55(2), 867-891.

Kim, Y., Park, M. S., \& Wier, B. (2012). Is earnings quality associated with corporate social responsibility? The Accounting Review, 87(3), 761-796.
La Porta, R., Lopez de Silanes, F., \& Shleifer, A. (1999). Corporate ownership around the world. The Journal of Finance, 54(2), 471-517.

Lawrence, A., Minutti-Meza, M., \& Zhang, P. (2011). Can Big 4 versus non-Big 4 differences in audit-quality proxies be attributed to client characteristics? The Accounting Review, 86(1), 259-286.

Ma, X., Yao, X., \& Xi, Y. (2006). Business group affiliation and firm performance in a transition economy: A focus on ownership voids. Asia Pacific Journal of Management, 23(4), 467-483.

McGuire, J., Sundgren, A., \& Schneeweis, T. (1988). Corporate social responsibility and firm financial performance. Academy of Management Journal, 31(4), 854-872.

McWilliams, A., \& Siegel, D. (2001). Corporate social responsibility: A theory of the firm perspective. The Academy of Management Review, 27(1), 117-127.

Minutti-meza, M. (2013). Does auditor industry specialization improve audit quality? Journal of Accounting Research, 51(4), 779-817.

Prior, D., Surroca, J., \& Tribó, J. A. (2008). Are socially responsible managers really ethical? Exploring the relationship between earnings management and corporate social responsibility. Corporate Governance: An International Review, 16(3), 160-177.

Shipman, J. E., Swanquist, Q. T., \& Whited, R. L. (2016). Propensity score matching in accounting research. The Accounting Review, 92(1), 213-244.

Waddock, S. A., \& Graves, S. B. (1997). The corporate social performance-financial performance link. Strategic Management Journal, 18(4), 303-319. 